\title{
TECHNICAL NOTES
}

An Outbreak of Horse Poisoning from Swamp Horsetail (Equisetum fluviatile L.) ${ }^{1}$

L. J. Klebesadel aNd W. W. MITCHELL $^{2}$

Research Agronomist and Taxonomist-ecologist, respectively, Alaska Agricultural Experiment Station, Palmer, Alaska.

Several species of horsetail (Equisetum spp.) have been reported to be poisonous to horses, particularly when large amounts are consumed in dried hay (Groh, 1930; Henderson et al., 1952; Muenscher, 1961). Species poisonous in hay are less dangerous or altogether harmless when ingested as fresh herbage with other forage species during the growing season (Groh, 1930; Muenscher, 1961). The genus Equisetum consists of approximately 25 species (Lawrence, 1951) with the following species known to cause poisoning (Muenscher, 1961): field horsetail ( $E$. arvense L.), scouringrush (E. hyemale L.), smooth scouring-rush (E. laevigatum A. Br.), marsh horsetail (E. palustre L.), wood horsetail (E. sylvaticum L.), and giant or ivory horsetail (E. telmateia Ehrh.).

Various theories have been proposed regarding the toxic principle in horsetails. These have associated the poisoning of horses with the presence of siliceous compounds, aconitic acid, and the alkaloid equisetin in the plants, and fungi sometimes found growing on the plants (Muenscher, 1961). More recently the presence of an antithiamine fac-

\footnotetext{
1 Joint contribution from the University of Alaska Agricultural Experiment Station and Tropic and Subarctic Research Programs, Crops Research Div., Agric. Research Serv., U. S. Dept. of Agriculture.

2 The authors express gratitude to Messrs. William Hoskins and Leo Kammermeyer, local residents, for assistance and information in this investigation.
}

tor has been demonstrated in horsetail and the enzymatic nature of this factor in thiamine destruction has been established (Henderson et al., 1952).

This report concerns a number of horse fatalities and 2 cases of sublethal poisoning presumed to have been caused by swamp horsetail ( $E$. fluviatile L.), a relatively tall horsetail that grows in shallow water (Figure 1). No previous accounts of poisoning by this species are known. The range of swamp horsetail is general in Alaska excepting the area north of the Brooks Range and the southwestern portion of the mainland (Hultén, 1941). The species is circumboreal and in North America it occurs southward to Oregon, North Dakota, Minnesota, Ohio, Pennsylvania and Delaware (Gleason, 1958).

An area of lowland flats near the mouth of the Matanuska River in southcentral Alaska has been utilized frequently by hunting guides and outfitters as winter range for horses. Infrequent previous horse deaths in that area have been attributed to malnutrition.

In November of 1963, approximately 50 horses were driven to this area to be left for the winter with occasional observation. Interaction of high tides and weather conditions not completely understood caused icing over much of the area usually occupied by the wintering horses, forcing them to venture inland to an area not ordinarily grazed. Eight to 10 dead horses were discovered, widely scattered in the latter area, over a month after they had been released on the lowland.

\section{Poisoning Symptoms}

When a number of the remaining horses were driven from the area the owner noted two that were abnormal in behavior. They exhibited several symptoms identical to those described in previous accounts of horsetail poisoning (Groh, 1930; Henderson et al., 1952; Muenscher, 1961). Symptoms observed

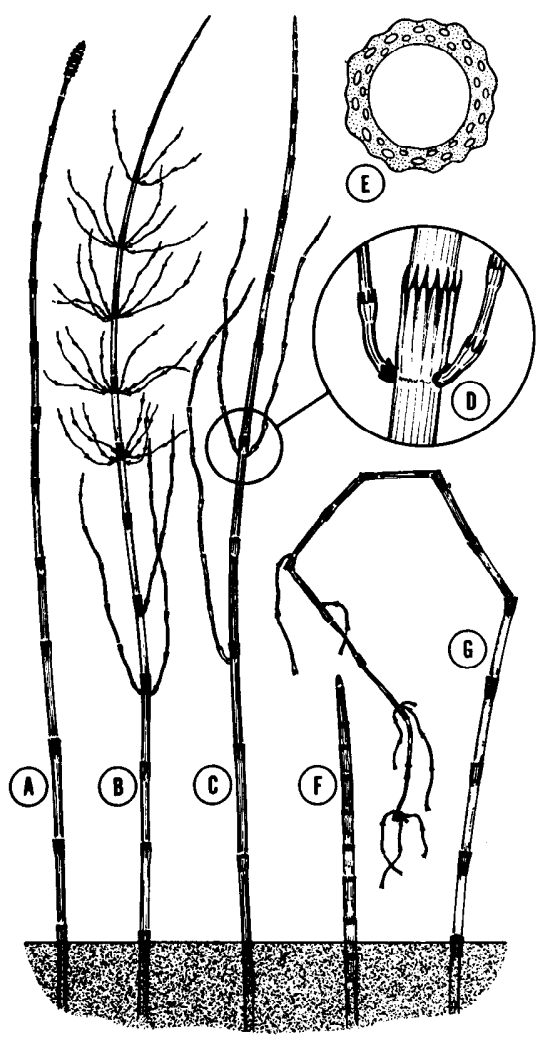

Figure 1. Various stem characteristics of swamp horsetail. A-unbranched conebearing stem; $\mathrm{B}$-stem with several whorls of many, fine branches; C-stem with few, large branches; D-detail of sheath; E-cross section of stem; $\mathrm{F}$ juvenile stem; G-partially senescent stem in winter. Stems similar to $F$ and G, especially the latter, comprised the forage consumed where poisoning of horses occurred.

were nervousness, rapid breathing, unsteadiness of gait, staggering and occasional falling. Heavy perspiration, not reported previously, was noted on both affected animals in spite of the low prevailing air temperature of winter and the nominal exertion of walking. One of the horses, 14 years old, avoided small icy areas in the roadway indicating that vision was unimpaired. Both animals recovered completely after a week of grazing on a mixed stand of 
bromegrass and mature oats. Beyond the symptoms described, all horses were reported to be in good physical condition.

Young horses develop symptoms and succumb to horsetail poisoning much more rapidly than older ones (Groh, 1930; Muenscher, 1961). Except as noted in the present report, ages of horses affected are not known.

Carcass Examination. - Carcasses of a yearling and a 7 to 8-year old horse were examined by the authors. Neither animal showed evidence of starvation. Stomach contents collected and examined microscopically revealed an abundance of swamp horsetail ingested. Post mortem examination of organs was precluded by the frozen condition of the carcasses and disruption of the abdominal cavities by carrion feeders. Fecal droppings showed no evidence of diarrhea, listed as an early symptom of horsetail poisoning (Groh, 1930).

\section{Circumstances of Poisonings}

The area in which the poisonings occurred was of very low relief and poor drainage. Inspection of the area was accomplished in mid-January about 10 days after deaths were first noted. Grazing activities could be reconstructed readily from tracks, pawings in the snow, and remains of plants eaten. Expanses of treeless bog were interspersed with dense stands of black spruce (Picea mariana) as seen in the background of Figure 2. A predominantly aquatic zone, consisting of small, shallow ponds and standing water, existed, for the most part, around the periphery of the spruce thickets. All water was sufficiently frozen to support horses at the time of their entry into the area so they were afforded unrestricted access to all vegetation present.

The horses had avoided the open, treeless bog except where trails crossed it. There was virtually no evidence of grazing in the bog arcas where vegetation consisted primarily of the low shrub sweet gale (Myrica

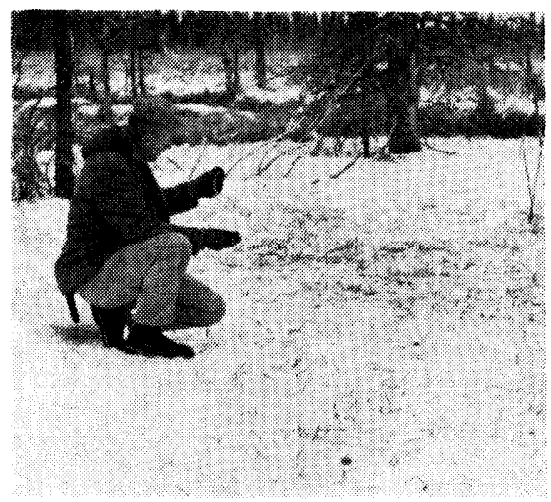

Figure 2. Stand of swamp horsetail heavily grazed by horses on a small, frozen, snow-covered pond.

gale) and tall-growing sedges (Carex spp.). Also present as sporadic plants were marsh cinquefoil (Potentilla palustris), bluejoint grass (Calamagrostis canadensis), and swamp horsetail. No horse tracks were found in the dense black spruce stands. The understory there consisted primarily of Labrador tea (Ledum groenlandicum) and tall grass clumps of bluejoint and arctagrostis (Arctagrostis arundinacea).

Evidence revealed a marked preference by the horses for foraging in the narrow zone bordering the black spruce thickets. (The two carcasses examined were found here.) Most of this zone was occupied by more or less continuous, shallow water in summer, as evidenced by the extent of ice-covered areas present. Thick stands of swamp horsetail grew in much of this water (Figure 2). Youthful alder (Alnus sp.) and occasional large, dead birch (Betula sp.) and black spruce were present in this zone. Species available for grazing included scattered clumps of bluejoint grass, scdges, and cotton grass (Eriophorum sp.) and occasional dried canes of the poisonous waterhemlock (Cicuta mackenzieana). Leather leaf shrub (Chamaedaphne calyculata) and marestail (Hippuris vulgaris), an emergent aquatic, were also present. None of these species showed evidence of having been grazed except for the sedge where leaves interspersed with swamp horsetail were occasionally eaten off.

In spite of the fact that several other species of plants were available to the horses, virtually all grazing was confined to swamp horsetail. Groh (1930) stated that one of the symptoms of horsetail poisoning was a strong craving for the weed. The upper portions of the horsetail stems were dried, colorless, and flaccid (Figure 1-G). The lower few inches of the stems, however, were green and succulent where they protruded through the ice and were available to the horses when snow was moved away (Figure 2). Grazing evidence revealed clearly that the horses were selective in seeking out this green herbage.

It is doubtful that swamp horsetail will ever become a widespread cause of poisoning. The aquatic habitat of this species precludes its harvest as hay during the growing season. It is unlikely that swamp horsetail is ever accessible to livestock in appreciable quantities except as in the present instance when plants were consumed during winter where they protruded through ice.

\section{Literature Cited}

Gleason, H. A. 1958. The new Britton and Brown illustrated flora of the northeastern United States and Canada. Vol. 1. Second Prtg. Lancaster Press, Inc., Lancaster, Penn. $482 \mathrm{pp}$.

GroH, H. 1930. Horsetail, a horsepoisoning weed. Canada Dept. Agr. Circ. 74.3 pp.

Henderson, J. A., E. V. Evans, AND R. A. McIntosh. 1952. The antithiamine action of Equisetum. Jour. Am. Vet. Med. Assoc. 120: 375.

Hulten, E. 1941. Flora of Alaska and Yukon. I. Pteridophyta, Gymmospermae and Monocotyledoneae. Lunds Universitets Arsskrift. Bd. $37.127 \mathrm{pp}$.

LAWRENCE, G. H. M. 1951. Taxonomy of vascular plants. The Macmillan Co., New York. 823 pp.

Muenscher, W. C. 1961. Poisonous plants of the United States. The Macmillan Co., New York. Rev. Ed. 277 pp. 